\title{
Krytycznie o niektórych metodach prowadzenia poszukiwań ukrytych zwłok
}

\author{
MACIEJ TrzCiŃSKI
}

ORCID: 0000-0002-6308-3187

Katedra Kryminalistyki

Wydział Prawa, Administracji i Ekonomii Uniwersytetu Wrocławskiego

\section{Wprowadzenie}

Problematyka prowadzenia poszukiwań ukrytych zwłok wpisuje się w szereg złożonych zagadnień, które przeważnie, choć nie zawsze, mają podłoże kryminalne. Prowadzone współcześnie poszukiwania osób zaginionych bardzo często mają swoje szczęśliwe zakończenie, niekiedy jednak okazuje się, iż poszukiwana osoba padła ofiarą zabójstwa, a jej zwłoki zostały przez sprawcę $\mathrm{w}$ jakiś sposób ukryte. Bywa również, iż prowadzone bezskutecznie poszukiwania w końcu doprowadzają do odnalezienia zwłok poszukiwanej osoby, która uległa nieszczęśliwemu wypadkowi (np. zamarzając w przecisku pod drogą) lub popełniła samobójstwo w trudno dostępnych, nietypowych warunkach ${ }^{1}$. Jest sprawą oczywistą, iż inaczej wygląda rutynowa metodyka poszukiwania osoby zaginionej, którą uważa się za osobę żyjącą ${ }^{2}$ inaczej realizowane są

1 Por. L. Szleszkowski et al., Ecological aspects of unusual findings of animals nesting inside a mummified human corpse in natural conditions, „Forensic Science International” 289, 2018, s. 390-396.

2 Działania w tym zakresie prowadzi policja przede wszystkim w oparciu o art. 14 ustawy z dnia 6 kwietnia 1990 roku o Policji (Dz.U. 1990 Nr 30, poz. 179 z późn. zm.) oraz Zarządzenie nr 48 Komendanta Głównego Policji z dnia 28 czerwca 2018 roku w sprawie 
działania zmierzające do odnalezienia zwłok osoby, co do której domniemuje się, iż padła ofiarą zabójstwa. W polskich realiach problematyką poszukiwania ofiar zabójstw obok organów ścigania zajmuje się również Instytut Pamięci Narodowej. Zdecydowaną większość tego typu prac poszukiwawczych prowadzi zgodnie ze swoimi kompetencjami Biuro Poszukiwań i Identyfikacji IPN ${ }^{3}$. Prace te koncentrują się na poszukiwaniu miejsc pochówku ofiar niemieckiego i sowieckiego totalitaryzmu oraz czystek etnicznych. W wypadku wielu tego typu zbrodni sprawcy często dokonywali zabiegów maskujących miejsca pochówków.

Tak więc na terenie kraju, obok poszukiwań ofiar współcześnie popełnianych zabójstw, prowadzone są poszukiwania ofiar zbrodni przeciwko pokojowi, ludzkości i przestępstw wojennych, które zgodnie ze standardami prawa krajowego i międzynarodowego nie ulegają przedawnieniu ${ }^{4}$. Warto w tym kontekście przypomnieć, iż zgodnie z art. $101 \S 1$ k.k. karalność zbrodni zabójstwa ustaje po upływie trzydziestu lat. Ten stosunkowo krótki okres przedawnienia wzbudza niekiedy kontrowersje, przede wszystkim w kontekście działań zmierzających do ustalenia niewykrytych sprawców zabójstw ${ }^{5}$. Policyjne Archiwa X realizują działania zmierzające przede wszystkim do wykrycia sprawcy zabójstwa, ale w toku prowadzonych czynności ujawniane są niekiedy informacje o kolejnych ofiarach sprawcy, które nigdy nie zostały odnalezione i figurują w rejestrze osób uznanych za zaginione. W takich sytuacjach podejmowane są przez policję czynności związane z poszukiwaniem ofiar zabójstwa 6 .

prowadzenia przez Policję poszukiwania osoby zaginionej oraz postępowania w przypadku ujawnienia osoby o nieustalonej tożsamości lub znalezienia nieznanych zwłok oraz szczątków ludzkich (Dziennik Urzędowy Komendy Głównej Policji 2018, poz. 77).

3 Szerzej: https://poszukiwania.ipn.gov.pl/ (dostęp: 4.02.2020).

4 Przede wszystkim art. 43 Konstytucji RP oraz art. 105 § 1 k.k.

5 W strukturach policji powołane zostały w 2007 roku zespoły funkcjonariuszy zajmujące się takimi sprawami. Potocznie zespoły te nazwano policyjnymi Archiwami X, choć faktycznie nazwa własna tych jednostek jest inna — szerzej: M. Zubańska, P. Knut, Niewykryte przestepstwa sprzed lat, nowoczesne narzędzia techniki kryminalistycznej $i$ policyjne Zespoły do spraw Przestepstw Niewykrytych, czyli crimen grave non potest esse impunibile, „Problemy Kryminalistyki” 299, 2018, nr 1, s. 8-19.

6 Ibidem, s. 17. 
Mówiąc o istocie prowadzenia poszukiwań ofiar zabójstw, wskazać trzeba dwa fundamentalne walory wynikające $\mathrm{z}$ odnalezienia takich zwłok i ustalenia ich tożsamości. Pierwszym z nich jest bez wątpienia wartość dowodowa. Funkcjonująca w potocznym odbiorze paremia ,nie ma trupa, nie ma sprawy" nie odpowiada, rzecz jasna, realiom. Również w polskiej rzeczywistości znane są już tzw. sprawy poszlakowe dotyczące zabójstw, kiedy udało się przypisać sprawcy winę, mimo braku możliwości odnalezienia ofiary zabójstwa. Tym niemniej odnalezienie zwłok i możliwość dokonania ich oględzin pozwolić może na określenie modus operandi sprawcy, a tym samym na ustalenie właściwej kwalifikacji prawnej. Czy traktować takie zabójstwo w typie podstawowym, czy też uznać je za zabójstwo ze szczególnym okrucieństwem? Specyficzny, powtarzający się sposób działania seryjnego sprawcy może pozwolić na określenie, iż przypadkowo odnalezione zwłoki można wiązać z kolejną jego ofiarą, tak więc obok walorów dowodowych odnalezienie zwłok może nieść również pewne korzyści wykrywcze. Trzeba również wspomnieć, iż odnalezienie zwłok osoby uznawanej przez lata za zaginioną pozwala zakończyć rodzinie zaginionej osoby trudny okres związany z prowadzeniem bezskutecznych poszukiwań. Identyfikacja ofiar zabójstw, również tych związanych z działaniami prowadzonymi przez IPN, jest w końcu możliwością przywrócenia tym osobom tożsamości i zapewnienia im prawa do godnego pochówku.

\section{Ukrycie zwłok jako próba uniknięcia odpowiedzialności}

W zasadzie codziennie docierają do nas ze środków masowego przekazu informacje o zabójstwach, których sprawcy stosują mniej lub bardziej wyrafinowane metody pozbycia się zwłok ${ }^{7}$. Działania te mają różny charakter w zależności od tego, czy zabójstwo było zaplanowane czy popełnione ad hoc w afekcie. Funkcjonujący w powszechnym odbiorze model zbrodni doskonałej opiera się na błędnym założeniu, że

7 Np. http://warszawa.wyborcza.pl/warszawa/7,54420,24990271,poszukiwania-5-letniego-dawida-zukowskiego-wznowione-nowe-nagrania.html (dostęp: 6.02.2020) lub https:// wiadomosci.gazeta.pl/wiadomosci/7,114883,24142937,morderstwo-a-potem-pocwiartowanie-zwlok-klotnia-bylych-kochankow.html\#s=BoxOpMT (dostęp: 6.02.2020). 
brak ciała ofiary stanie się gwarancją bezkarności dla zabójcy. Problematyka ta była w ostatnich latach przedmiotem szczegółowych badań ${ }^{8}$. Działania sprawców mają bardzo różnorodny charakter od defragmentowania zwłok i próby ich ukrycia w różnych miejscach, przez spalenie lub rozpuszczenie w substancjach chemicznych, po bodaj najczęściej podejmowane próby zakopania, zabetonowania zwłok lub ich utopienia $\mathrm{w}$ zbiorniku wodnym ${ }^{9}$. Niewątpliwie o tym, jakie zabiegi podejmie sprawca zabójstwa w celu ukrycia lub, lepiej powiedzieć, pozbycia się zwłok, decyduje miejsce, w jakim doszło do zabójstwa, oraz fakt, czy było ono starannie zaplanowane czy doszło do niego przez przypadek, np. sprawca pobił ofiarę ze skutkiem śmiertelnym. Nie bez znaczenia będzie również to, jakimi środkami dysponuje sprawca oraz czy działał on w pojedynkę czy w ramach zorganizowanej grupy. Można w tym miejscu przywołać przykłady licznych zbrodni wojennych (Katyń 1940) lub zbrodni ludobójstwa (Srebrenica 1995), kiedy zorganizowany sposób działania sprawców miał m.in. za zadanie skutecznie ukryć i zamaskować masowe pochówki ${ }^{10}$. Działania pojedynczych sprawców, których celem jest pozbycie się przeważnie pojedynczych zwłok, przyjmują, rzecz jasna, nieco inny charakter. Zaskakiwać może niekiedy pewna naiwność sprawców, zwłaszcza tych, którzy dokonali zabójstwa ad hoc. Pozbycie się zwłok postrzegane jest przez nich niekiedy dosłownie, a ich działania mają często prymitywny charakter. Wywiezienie zwłok do lasu i porzucenie ich lub rozkawałkowanie ${ }^{11}$ i porzucenie na wysypisku śmie-

8 Por. A. Gawliński, Jak pozbyć się zwłok. Specyfika działania sprawców zabójstw i ich postępowanie ze zwłokami, Olsztynek 2018.

9 Szerzej ibidem, s. 107-295.

10 W wypadku zbrodni katyńskiej było to m.in. nasadzanie młodych drzew w miejscach pochówków, natomiast w wypadku zbrodni popełnianych na Bałkanach było to np. nawożenie na masowe groby gruzu budowlanego, który miał utrudnić identyfikację satelitarną. W obu wypadkach działania takie można traktować jako formę maskowania pochówków.

11 Defragmentacja ciała ofiary ma przede wszystkim praktyczny charakter. Sprawca chce w ten sposób usprawnić swoje działania związane z przemieszczeniem zwłok z miejsca zabójstwa do planowanego miejsca (lub miejsc) ich ukrycia - szerzej: T. Konopka, M. Strona, F. Bolechała, Zabójstwo z rozkawałkowaniem zwłok - mity i rzeczywistość, [w:] E. Gruza, M. Goc, T. Tomaszewski, Co nowego w kryminalistyce - przeglad zagadnień z zakresu zwalczania przestępczości, Warszawa 2010, s. 141-148. 
ci trudno uznać za przemyślaną i wyrafinowaną metodę. Trudno w takich wypadkach mówić również o intencjonalnym ukryciu zwłok, a raczej o podejmowanych w pośpiechu działaniach pozbycia się zwłok, co wynikać może nie tylko z chęci uniknięcia odpowiedzialności karnej, ale również z niechęci i strachu związanego z obcowaniem ze zwłokami.

Na sposób, w jaki sprawcy zabójstw pozbywają się zwłok, niewątpliwy wpływ ma poziom ich inteligencji oraz zdobyta wiedza, która buduje zgoła iluzoryczne wyobrażenie tego, jak skutecznie można tego dokonać. W tym kontekście pojawiają się dwa nietożsame pojęcia, tj. ,,pozbycie się zwłok” oraz „ukrycie zwłok”. Zabiegi związane z pozbyciem się zwłok można rozumieć dosłownie jako rodzaj ich unicestwienia, dosłownego zniszczenia, np. spalenia lub rozpuszczenia w substancjach chemicznych, choć oczywiście każda tego typu operacja pozostawi ślady, które wychwycić mogą technicy kryminalistyki. W niektórych do dzisiaj występujących obrzędach pogrzebowych obok powszechnego ciałopalenia występują również inne rytualne formy funkcjonujące od stuleci ${ }^{12}$. Powszechność i dostępność różnych nośników informacji kształtuje naszą wiedzę i wyobrażenie w zakresie traktowania zwłok — od sacrum do profanum. Uwarunkowania te, w tym również aspekty kulturowe i religijne, mogą mieć wpływ na to, jak ze zwłokami ofiary postąpi zabójca. Problematyka ta wpisuje się w zagadnienia z zakresu antropologii kulturowej, behawiorystyki człowieka, religioznawstwa, a w węższym zakresie $\mathrm{w}$ problematykę podejmowaną przez tanatologię ${ }^{13}$. Ukrycie zwłok jest poniekąd formą pozbycia się ich, lecz związane jest z intencjonalnymi zabiegami człowieka, który działa według pewnego planu, dobierając miejsce ukrycia i niekiedy formy jego zamaskowania. Rozważania podjęte $\mathrm{w}$ niniejszym artykule dotyczą właśnie sytuacji związanych z intencjonalnym ukryciem zwłok, choć, rzecz jasna, obok wyrafinowanych form ukrywania i maskowania miejsca pochówku wciąż odnotowywane są prymitywne formy ukrycia zwłok polegające np. na ich porzuceniu

12 Np. w Tybecie do dzisiaj funkcjonuje tzw. pogrzeb powietrzny (niebiański pogrzeb), który jest buddyjską formą pochówku zwłok ludzkich, spotykaną w Azji, w wyniku której zwłoki stają się żerem dla ptaków drapieżnych.

13 Por. E. Domańska, Nekros. Wprowadzenie do ontologii martwego ciała, Warszawa 2017; Ph. Aries, Człowiek i śmierć, Warszawa 1989. 
w lesie i przykryciu gałęziami lub ukryciu bezpośrednio w miejscu, gdzie doszło do zbrodni ${ }^{14}$.

\section{Metodyka prowadzenia poszukiwań - pytania o skuteczność}

Analiza spraw sądowych ${ }^{15}$ oraz częste doniesienia medialne potwierdzają dość wyraźnie, iż najczęściej sprawcy zabójstw próbują ukryć zwłoki, zakopując je bądź, co rzadsze, topiąc w zbiornikach wodnych, czasami je uprzednio defragmentując ${ }^{16}$.

Problematyka poszukiwań ofiar zabójstw jest obecna w literaturze kryminalistycznej ${ }^{17}$, choć brak przekrojowych i analitycznych opracowań. Autor prowadzi w tym zakresie badania, które zmierzają do przedstawienia tego, jak kryminalistyka oraz archeologia sądowa przyczyniają się lub mogą się przyczynić do efektywniejszych działań związanych

14 Bywa, iż zabójca zupełnie naiwnie próbuje ukryć zwłoki w mieszkaniu, w którym doszło do zabójstwa, np. w wersalce — zob. https://www.fakt.pl/wydarzenia/polska/ lodz/zamordowal-kaje-a-zwloki-ukryl-w-wersalce-w-lodzi-zaczyna-sie-proces/cxhsztk (dostęp: 10.02.2020) lub w walizce, która przechowywana była w garażu zabójcy — zob. https://www.tvp.info/37101801/zamordowal-znajoma-ukryl-cialo-w-walizce-akwarystaskazany-na-25-lat (dostęp: 10.02.2020).

${ }^{15}$ A. Gawliński, op. cit., s. $111 \mathrm{n}$.

${ }^{16}$ Przykładem takiej sprawy może być zabójstwo znanej dziennikarki Kim Wall, do którego doszło w 2017 roku w Danii. Sprawca zabójstwa, ekscentryczny konstruktor Peter Madsen, rozczłonkował zwłoki ofiary, zapakował i obciążył, aby zatopić je w morzu. W trakcie podjętych przez policję czynności udało się przy pomocy psów tropiących zlokalizować i wyłowić zatopione fragmenty ciała. Szerzej: http://enfsi.eu/agenda/forensic-search-and-recovery-clandestine-graves/ (dostęp: 9.02.2020). W Polsce znana jest sprawa określana przez media kryptonimem „Skóra”. W 1998 roku dwudziestotrzyletnia studentka Uniwersytetu Jagiellońskiego została brutalnie zamordowana, a jej rozkawałkowane zwłoki zostały przez sprawcę wrzucone do Wisły — szerzej: https://pl.wikipedia. org/wiki/Morderstwo_Katarzyny_Zowady (dostęp: 10.02.2020).

17 Por. J. Stojer-Polańska, M. Lisowicz, J. Gołębiowski, Kryminalistyczne aspekty poszukiwania zwłok, „Problemy Kryminalistyki” 289, 2015, nr 3, s. 3-10; M. Trzciński, Wspótczesne metody poszukiwań ukrytych zwłok, „Acta Universitatis Lodziensis. Folia Iuridica" 83, 2018, s. 7-20; E. Mazurkiewicz, A. Kubacki, J. Karczewski, Poszukiwania miejsc pochówków $w$ gruncie za pomoca nowoczesnych metod badawczych, [w:] V. Kwiatkowska-Wójcikiewicz, D. Wilk, J. Wójcikiewicz, Kryminalistyka a nowoczesne technologie, Kraków 2019, s. 19-30. 
z prowadzeniem tego typu poszukiwań. W niniejszym artykule przedstawiono jedynie wstępne uwagi dotyczące możliwości, ale również ograniczeń, związanych ze stosowaniem niektórych metod, w tym urządzeń angażowanych podczas prowadzonych poszukiwań. Działania tego typu realizowane są w Polsce dwojako, tj. w toku działań operacyjno-rozpoznawczych oraz w ramach prowadzonego postępowania przygotowawczego. W zasadzie w obu sytuacjach istnieje możliwość zaangażowania tego samego instrumentarium i tych samych metod działania. Praktyka wskazuje jednak, iż w postępowaniu przygotowawczym, co wydaje się zrozumiałe, organ procesowy częściej korzysta z możliwości powołania biegłego lub specjalisty, który poza wiedzą i kompetencjami dysponuje również specjalistycznym sprzętem (np. georadarem). Inną kwestią są oczywiście środki finansowe, jakimi dysponują organy procesowe, aby sfinansować na ogół dość kosztowne, czasami kilkudniowe prace w terenie. Niestety polska policja nie jest wciąż odpowiednio doposażona, jeśli idzie np. o sprzęt z zakresu geofizyki ${ }^{18}$, stąd też często musi tego typu badania zlecać biegłym spoza struktur policji.

Bez wątpienia, podejmując próby poszukiwań zwłok, organy ścigania bazują przede wszystkim na analizie kryminalnej, której wynikiem jest wytypowanie lokalizacji domniemanego miejsca ukrycia zwłok. Istnieje, rzecz jasna, szereg różnych źródeł informacji, które muszą zostać poddane analizie. Bardzo często są to informacje pochodzące od świadków, niekiedy od skruszonych przestępców, którzy sami chcą wskazać miejsce ukrycia zwłok. Informacje pozyskane od osobowych źródeł dowodowych mogą być, jak wiemy, niewiarygodne z powodu nieszczerości składanych wypowiedzi, a jednocześnie po kilku lub kilkudziesięciu latach od zabójstwa nawet skruszony zabójca może mieć problem ze wskazaniem miejsca ukrycia zwłok, co będzie wynikiem np. zmieniającego się ukształtowania terenu oraz obiektywnych kłopotów z pamięcią. Kryminalistyka $\mathrm{w}$ takich wypadkach dysponuje, rzecz jasna, instrumentarium pozwalającym na dokonanie weryfikacji składanych zeznań, przede

18 Z ustaleń autora wynika, iż dość często w takich pracach wykorzystywany jest georadar. Urządzenie takie w 2019 roku posiadały komenda wojewódzka policji w Katowicach oraz komenda główna policji w Warszawie. Trzeba przy tej okazji wyraźnie podkreślić, iż obsługa takiego urządzenia wymaga doświadczenia - niezbędna jest umiejętność szybkiej interpretacji wyników badań. 
wszystkim w związku z badaniami poligraficznymi ${ }^{19}$. Istotnym źródłem informacji mogą okazać się różnego rodzaju dokumenty (zwłaszcza jeśli idzie o sprawy prowadzone przez IPN), nagrania monitoringu czy wreszcie analiza danych telekomunikacyjnych, które mogą pomóc w prześledzeniu przemieszczania się zarówno ofiary, jak i jej oprawcy. Kluczowym wydaje się zakreślenie właściwego związku przestrzennego pomiędzy: przestępstwem, przestępcą, ofiarą oraz środowiskiem, w czym pomocny może okazać się system GIS (Geographic Information System) ${ }^{20}$. W wypadku zatrzymanej osoby podejrzewanej o dokonanie zabójstwa i ukrycie zwłok pomocne mogą okazać się ponadto badania mikrośladów ujawnionych na odzieży lub obuwiu podejrzanego, np. w zakresie przeprowadzenia badań śladów gleby i materiałów geologicznych. Dopiero po wytypowaniu lokalizacji można podjąć decyzję o tym, jakie metody oraz urządzenia mogą okazać się pomocne. Niestety bardzo rzadko zdarza się, iż wskazywana jest przez świadka precyzyjna lokalizacja. Oczywiście inaczej sytuacje te wyglądają w terenie otwartym, inaczej w terenie zabudowanym, gdzie łatwiej o zapamiętanie stałego punktu odniesienia. Na ogół jednak organy ścigania stają przed koniecznością prowadzenia tego typu poszukiwań na obszarze co najmniej kilku arów lub dokonania takich badań w kilku typowanych miejscach.

Jest sprawą oczywistą, iż nie istnieje żaden gotowy algorytm działania, każda bowiem sprawa dotycząca poszukiwania ofiary zabójstwa jest inna. Uwagi zawarte w niniejszym artykule odnoszą się jedynie do metod poszukiwań zwłok ukrytych w gruncie. Dokonanie przez sprawcę takiego zabiegu nie zawsze musi wiązać się z koniecznością kopania przez niego intencjonalnej jamy grobowej. Znane są bowiem przypadki, kiedy sprawcy zabójstwa, upraszczając swoje działania, np. wykorzystują istniejące zaklęśnięcia terenu, stare wykopy lub leje po ostrzale artyleryjskim ${ }^{21}$, aby ukryć w nich zwłoki. Trzeba również wziąć pod uwagę

19 Por. R. Jaworski, Poligraficzny ,, test wydobywczy” przy poszukiwaniu ciała ofiary zabójstwa, „Wrocławskie Studia Sądowe” 4, 2012, nr 3, s. 50-59.

20 E. Mazurkiewicz, A. Kubacki, J. Karczewski, op. cit., s. 23.

21 Z takim przypadkiem spotkał się autor, uczestnicząc w pracach poszukiwawczych oraz późniejszych ekshumacjach prowadzonych przez IPN w miejscowości Stary Grodków. W 2016 roku ujawniono tam masową mogiłę około trzydziestu osób, które zostały zamordowane przez służbę bezpieczeństwa we wrześniu 1946 roku. Część 
sytuacje, kiedy ukryte zwłoki są później wtórnie przemieszczane w inne miejsce. Trafne wydają się tu spostrzeżenia doświadczonego antropologa sądowego S. Black, iż

Pierwotne miejsca ukrycia zwłok wybierane są zwykle ze względu na wygodę i bliskość miejsca zbrodni. Często są one też znane sprawcy. Ponieważ większość morderstw to zbrodnie w afekcie, na ogół ukryciem ciała i dowodów pośrednich rządzi panika. Jednak później, po przemyśleniu pewnych spraw, zabójca nierzadko wraca do miejsca, w którym pierwotnie ukrył zwłoki, i przenosi je w bezpieczniejsze miejsce, zwykle położone dalej od miejsca zbrodni. Jako że wybór kolejnej lokalizacji jest bardziej przemyślany, drugie miejsce ukrycia szczątków znacznie trudniej przewidzieć, a trzecie często jeszcze trudniej ${ }^{22}$.

Nie ulega wątpliwości, iż podstawową kwestią związaną z poszukiwaniem ofiary zabójstwa jest zatem określenie terenu, na którym poszukiwania mają być prowadzone.

Zgodnie z zaproponowaną już przez autora klasyfikacją ${ }^{23} \mathrm{w}$ takich sprawach sięgnąć można po metody nieinwazyjne, tj. prospekcję powierzchniową terenu (oględziny), metody związane z teledetekcją, przede wszystkim użycie lotniczego skaningu laseroweego LIDAR (Light Detection and Ranging), które mogą pomóc wygenerować numeryczny model terenu i w efekcie pomóc dostrzec zmiany w jego ukształtowaniu (np. wkopy, nasypy). W procesie analizy zmian w terenie wykorzystuje się ponadto ortofotomapy, analizę archiwalnych zdjęć lotniczych i satelitarnych. Coraz powszechniej $\mathrm{w}$ procesie bezinwazyjnego poszukiwania miejsc pochówków wykorzystuje się również metody geofizyczne (detektor metalu, georadar, magnetometr, rzadziej metodę elektrooporową). Bardzo sporadycznie, zwłaszcza w polskich warunkach, wykorzystuje się w procesie poszukiwań ukrytych zwłok kamery termowizyjne ${ }^{24}$. Zadaniem tych nieinwazyjnych metod jest uchwycenie w terenie anomalii, różnic na ogół niewidocznych ,gołym okiem”, które pozwolą wytypować lokalizacje do późniejszej weryfikacji. Metody te mogą okazać się pomocne w zrekon-

zdefragmentowanych zwłok upchnięto w dość płytkich lejach po eksplozji pocisków moździerzowych.

22 S. Black, Co mówia zwłoki, Łódź 2019, s. 188.

23 M. Trzciński, op. cit., s. 12-17.

${ }^{24} \mathrm{~W}$ istocie ich przydatność przy tego typu działaniach jest ograniczona do dużych i stosunkowo płytko zakopanych obiektów. Nadto wyniki badań będą uzależnione od pory roku (kwestia emitowania odbijanego przez obiekt ciepła). 
struowaniu krajobrazu z okresu, kiedy doszło do popełnienia przestępstwa, co wydaje się absolutnie kluczowe. Niekiedy, zwłaszcza w terenie otwartym, przydatna może okazać się obserwacja ukształtowania terenu oraz zmieniającej się wegetacji. Po wytypowaniu miejsc do sprawdzenia sięga się po metody inwazyjne - przede wszystkim po odwierty geologiczne (przy „świeżych” pochówkach z udziałem cadaver dog, czyli psa tropiącego), wkopy sondażowe metodą archeologiczną wraz z analizą stratygraficzną, szerokopłaszczyznowe prace ziemne przy użyciu sprzętu ciężkiego, pobieranie próbek gruntu do analizy chemicznej (np. metoda fosforowa).

W polskich warunkach organy ścigania podejmujące poszukiwania ofiar zabójstw, co do których istnieje domniemanie, iż zostały pogrzebane w ziemi lub np. zabetonowane w obrębie istniejącej zabudowy domu mieszkalnego lub pomieszczeń gospodarczych, często używają metod geofizycznych (przede wszystkim georadaru) oraz wykorzystują w poszukiwaniach psy tropiące zwłoki.

Podjęcie konkretnych działań przez organy ścigania generuje oczywiście szereg kosztów oraz problemów administracyjno-prawnych związanych np. z uzyskaniem zgód właścicieli terenu, na którym będą prowadzone poszukiwania, zajęciem pasa ruchu drogowego czy koniecznością przywrócenia stanu poprzedniego w wypadku rozbiórki fragmentu nawierzchni drogi itp. Jeśli poszukiwania zakończą się sukcesem, poniesione nakłady nie będą razić, jeśli natomiast zakończą się niepowodzeniem, powstanie szereg pytań, podsycanych niekiedy przez media, czy podjęte działania były uzasadnione, czy realizowano je według starannie przeanalizowanego planu, czy koszty nie mogły być niższe itp. ${ }^{25} \mathrm{~W}$ oparciu o zdobyte doświadczenia praktyczne ${ }^{26} \mathrm{i}$ analizę akt spraw można stwierdzić, iż w polskich warunkach poszukiwania ofiar zabójstw dokonywane

${ }^{25}$ Z taką sytuacją spotkała się m.in. policja brytyjska, prowadząc w 1976 roku poszukiwania Renee i Andrew MacRae. Prace poszukiwawcze prowadzone przy zaangażowaniu wielu środków i osób trwały ponad cztery tygodnie i kosztowały 110 tysięcy funtów. Poszukiwania zakończyły się fiaskiem, a na policję spadła fala krytyki — por. S. Black, op. cit., s. 186-190. Tym niemniej w 2019 roku policja zatrzymała osobę podejrzaną o popełnienie tych zabójstw - https://www.scotsman.com/news/crime/renee-and-andrew-macrae-manarrested-43-years-after-disappearance-of-mother-and-son-1-5002093 (dostęp: 10.02.2020).

${ }^{26}$ Autor miał możliwość uczestniczenia w 2014 roku jako biegły konsultant w działaniach operacyjnych prowadzonych przez komendę wojewódzką policji we Wrocławiu w związku z poszukiwaniem ofiary zabójstwa oraz kilkukrotnie uczestniczył w pracach 
są przez policję przede wszystkim w oparciu o wykorzystywanie georadaru, odwiertów geologicznych oraz psów tropiących zwłoki ${ }^{27}$, oczywiście po uprzednim wytypowaniu domniemanego miejsca ukrycia zwłok. Bardzo podobnie realizowane są tego typu poszukiwania w innych krajach, zwłaszcza zachodnioeuropejskich (np. w Niemczech, Danii, Francji, Holandii). Trudno jest bez przeprowadzenia wnikliwych analiz i badań ocenić efektywność, wydolność każdej z tych metod. Tym niemniej autor ma w tym zakresie pewne wstępne krytyczne uwagi, które wynikają m.in. z możliwości obserwacji, jak metody te sprawdzają się w Polsce, a jak w innych krajach europejskich. Nie ulega wątpliwości, iż użycie metod geofizycznych może znaleźć swoje zastosowanie w lokalizacji obiektów znajdujących się pod ziemią. Metody te stosowane są z powodzeniem w toku badań archeologicznych podczas lokalizacji np. reliktów architektonicznych, komór grobowych itp. Organy ścigania wykorzystują metody geofizyczne (przede wszystkim badania georadarowe) ${ }^{28}$ podczas lokalizacji nie tylko pochówków, lecz również innych obiektów, np. ukrytych po ziemią lub zabetonowanych w posadzkach, ścianach rzeczy pochodzących z przestępstwa ${ }^{29}$. Można w tym momencie postawić kluczowe pytanie o to, jakie są nasze oczekiwania względem tego urządzenia. Jest to bowiem jedno z urządzeń geofizycznych, które uchwycić może wyłącznie anomalie w gruncie ${ }^{30}$. Odbijane od znajdujących się pod

poszukiwawczych oraz ekshumacjach ofiar zbrodni komunistycznych prowadzonych przez Biuro Poszukiwań i Identyfikacji IPN.

27 Zaangażowanie psa tropiącego zwłoki związane jest z wcześniejszym nakłuciem gruntu w celu uwolnienia zapachu, jednak ten rodzaj ingerencji w grunt nie jest de facto uważany za formę odwiertu geologicznego. Odwierty geologiczne wykonywane są przy użyciu specjalnych wiertnic geologicznych.

28 Bardziej zaawansowane badania elektrooporowe gruntu są bardziej pracochłonne i wymagają większego doświadczenia od operatora. Nie bez znaczenia jest oczywiście koszt takiego sprzętu, jego dostępność oraz dobre opanowanie jego obsługi. Z tego też powodu najczęściej używany do poszukiwania ukrytych zwłok jest georadar. W wypadku poszukiwań ukrytych przedmiotów pochodzących z przestępstwa (np. broni, kosztowności) swoje zastosowanie znaleźć mogą magnetometry oraz detektor metalu.

29 P.M. Barone, Geophysics and Archaeology at Crime Scenes, [w:] Multidisciplinary Approaches to Forensic Archaeology, red. P.M. Barone, W.J. Groen, Springer 2018, s. $41-57$.

30 Por. https://pl.wikipedia.org/wiki/Georadar (dostęp: 10.02.2020). 
ziemią przeszkód fale elektromagnetyczne są rejestrowane, a profile georadarowe interpretowane są często na bieżąco przez operatora.

Zatem urządzenie to może wskazać w gruncie, również w betonowej posadzce, ścianie budynku, szeroko rozumiane ,anomalie”. Nie jest to bynajmniej „wykrywacz zwłok” i nie pokaże nam ich w gruncie w sposób dosłowny. Wokół urządzenia tego narosło niestety sporo nieporozumień, m.in. w sprawie podjętych w 2015 roku poszukiwań legendarnego Złotego Pociągu na Dolnym Śląsku, kiedy to ówczesny wiceminister kultury i dziedzictwa narodowego zaprezentował przed kamerami telewizyjnymi wydruk z georadaru, na którym miał być rzekomo widoczny ukryty pod ziemią pociąg ${ }^{31}$. Nadinterpretacja wyników badań georadarowych lub zwykły brak doświadczenia w obsłudze tego urządzenia były już nie raz powodem rozczarowań, które w efekcie przyczyniają się do dezawuowania realnych możliwości skutecznego użycia tego urządzenia w procesie poszukiwań ukrytych zwłok. Autor spotkał się już wielokrotnie z badaniami georadarowymi, które wykorzystywane były m.in. przez Biuro Poszukiwań i Identyfikacji IPN oraz policję i prokuraturę powszechną w sprawach poszukiwań ofiar zabójstw. Niestety w żadnej z tych spraw badania te nie wskazały na miejsce pochówku, co nie oznacza bynajmniej, iż nie były w całym procesie poszukiwań przydatne. Wyniki georadarowe są, rzecz jasna, weryfikowane metodami inwazyjnymi w postaci odwiertów lub wkopów sondażowych. Jeśli w ich wyniku nie doszło do odkrycia pochówku, to nie oznacza, iż metody goeofizyczne należy uznać za nieprzydatne. Słusznie zauważa S. Black, iż ,jeśli nie udaje nam się odnaleźć tego, co chcieliśmy, musimy pogodzić się z tym, że szukaliśmy w złym miejscu i nie mogliśmy znaleźć czegoś, czego tam nie ma"32. Bez wątpienia natomiast urządzenie to pozwala często definitywnie wyeliminować typowane miejsca pochówków. Bywa, iż po badaniach takich, zwłaszcza w kontekście zbrodni o charakterze historycznym, dochodzi do swego rodzaju odmitologizowania miejsca, które uświęcone w lokalnej tradycji uważane było za miejsce pochówku, np. ofiar zbrodni komunistycz-

${ }^{31}$ Akcja poszukiwań zakończyła się niepowodzeniem oraz zażartą polemiką obu ekip, które prowadziły w domniemanym miejscu ukrycia owego pociągu badania geofizyczne. Wyniki tych badań ewidentnie się wykluczały.

32 S. Black, op. cit., s. 190. 
nych ${ }^{33}$. Aby zdiagnozować zarówno efektywność używanego sprzętu, jak i kwalifikacje wykonujących te badania, najlepiej jest zaaranżować tego typu poszukiwania na przygotowanym terenie po uprzednim ukryciu (zakopaniu) konkretnych obiektów. Autor przeprowadził takie praktyczne warsztaty w 2019 roku na terenie jednostki policji we Wrocławiu przy ul. Połbina 1. Na głębokości 75-80 cm zakopano manekina o wysokości około $165 \mathrm{~cm}$ imitującego ludzkie zwłoki, w drugim miejscu na podobnej głębokości ukryto walizkę wypetnioną m.in. metalowymi atrapami broni palnej, odstrzeloną amunicją. Podczas przeprowadzonych warsztatów wykorzystano również dwa psy tropiące zwłoki ${ }^{34}$.

Badania georadarowe przeprowadziło dwóch ekspertów, każdy używał swojego własnego urządzenia. Obaj eksperci zostali poinformowani, jakie obiekty są przedmiotem poszukiwań, nie poinformowano ich natomiast, na jakiej głębokości zostały one zakopane. Wyniki przeprowadzonych badań nie wskazały miejsca ukrycia obiektów. Natomiast użycie magnetometru oznaczyło jako jedno z kilku miejsc lokalizację ukrytej walizki wypełnionej metalowymi obiektami. Teren, na którym prowadzono poszukiwania, był trudny, obfitował bowiem w dużą ilość gruzu oraz metalowych obiektów znajdujących się pod ziemią, co było wynikiem m.in. działań wojennych prowadzonych w tym miejscu w 1945 roku.

Obaj eksperci wykonywali swoje prace niezależnie, dobierając częstotliwość anteny na poziomie 450-500 MHz. Na poważne ograniczenia użycia georadaru w strefie zurbanizowanej zwracano już uwagę $e^{35}$. Rów-

${ }^{33}$ Autor uczestniczył w poszukiwaniach prowadzonych w 2016 roku przez IPN w Sieradzu przy ul. Polskiej Organizacji Wojskowej 27. Na podstawie informacji lokalnych historyków oraz przeprowadzonych wcześniej badań georadarowych wytypowano konkretną lokalizację miejsca domniemanego grobu masowego ofiar zbrodni komunistycznych. Przeprowadzone w tym miejscu badania archeologiczne wykluczyły jednoznacznie, iż wskazane miejsce kryło jakiekolwiek szczątki ludzkie — szerzej: T. Borkowski, M. Trzciński, Sprawozdanie z badań archeologicznych na posesji przy ul. Polskiej Organizacji Wojskowej 27 w Sieradzu, pow. Sieradzki, woj. Łódzkie, dziatka 172/17. Egzemplarz sprawozdania znajduje się w Biurze Poszukiwań i Identyfikacji IPN we Wrocławiu.

34 Zakopany manekin nasączony został przez funkcjonariuszy policji syntetycznym preparatem Sigma stosowanym przez polską policję podczas treningów cadaver dogs.

35 E. Mazurkiewicz, M. Łyskowski, Zastosowanie metody georadarowej do badania miejsc pochówków na terenach zurbanizowanych, [w:] Kryminalistyka — jedność 
nież i w tym wypadku badania te okazały się zawodne. Nie można, rzecz jasna, dyskwalifikować metod geofizycznych w zakresie poszukiwań ukrytych zwłok, warto jednak zaznaczyć, iż czym innym jest wykorzystywanie tych metod w toku tradycyjnych badań archeologicznych, czym innym natomiast poszukiwania pojedynczego grobu w trudnym terenie. W przeciwieństwie do innych krajów zachodnioeuropejskich w Polsce nie wykształciła się jeszcze specjalizacja tzw. geofizyki sądowej (forensic geophysics), której przedstawiciele wyraźnie koncentrują się na praktycznym wykorzystaniu geofizyki w działaniach wykrywczych prowadzonych przez organy ścigania. Można tu zatem mówić o braku właściwego doświadczenia, nie zaś o zawodności samej metody lub sprzętu.

Również jeśli idzie o skuteczność wykorzystywania psów tropiących zwłoki, autor pragnie wnieść głos krytyczny. W toku opisywanych powyżej działań praktycznych psy policyjne ${ }^{36}$, mające podjąć ślad zapachowy i oznaczyć miejsce lokalizacji ,zwłok”, nie zrobiły tego, mimo iż obiekt oznaczony został przez funkcjonariuszy policji preparatem wykorzystywanym w toku szkolenia psów ${ }^{37}$. Warto zadać sobie pytanie dotyczące skuteczności działań psów tropiących zwłoki. Od ukrycia oznakowanych zapachem ,zwłok” do podjęcia ich poszukiwań minęło sześć miesięcy. W relacjach policjantów prowadzących wraz z psami takie poszukiwania przewijają się informacje, iż pies w toku szkolenia na ogół bez trudu wskazuje próbkę oznaczoną preparatem Sigma, który imitować ma zapach rozkładających się zwłok. Jednak w terenie podczas praktycznych działań skuteczność ta jest znacznie mniejsza. Co jest tego powodem? Oczywiście analiza wszystkich uwarunkowań wykracza poza ramy niniejszego artykułu, tym niemniej autor ustalił, iż polska policja bazuje podczas szkoleń na syntetycznym preparacie, nie zaś na oryginalnym zapachu ludzkich zwłok. System szkoleń we Francji, Danii oraz Holandii bazuje na oficjalnym, legalnym wykorzystaniu tzw. konserw zapachowych przygotowanych w oparciu o odpady biologiczne w zakładach medycyny sądowej. W ostatnich latach również niemiecka policja

nauki i praktyki. Przegląd zagadnień z zakresu zwalczania przestępczości, red. M. Goc, T. Tomaszewski, R. Lewandowski, Warszawa 2016, s. 45-51.

36 Podczas ćwiczeń wykorzystano dwa psy z komendy miejskiej policji we Wrocławiu.

37 Na temat procedury szkolenia w tym zakresie psów m.in.: R. Ośka, M. Lisowicz, Wyszukiwanie zapachu zwłok ludzkich, Legionowo 2016. 
zrezygnowała z wykorzystywania preparatu Sigma na rzecz „oryginalnego" zapachu, który emitują zwłoki.

W tej sytuacji wydaje się, iż również w Polsce w celu podniesienia efektywności wykorzystywania w procesie poszukiwań ukrytych zwłok psów tropiących zwłoki należałoby wycofać z procesu szkolenia preparat Sigma na rzecz bardziej wiarygodnych i, jak się okazuje, skuteczniejszych metod szkolenia opartych o naturalny zapach zwłok.

Trzeba jednoznacznie stwierdzić, iż wbrew funkcjonującemu stereotypowi wykorzystanie odpadów biologicznych podczas procesu szkolenia psów tropiących zwłoki również w polskich warunkach prawnych jest dopuszczalne ${ }^{38}$.

\section{Wnioski}

Badanie efektywności metod wykorzystywanych podczas poszukiwań ofiar zabójstw to proces złożony oparty, z jednej strony, na analizie już zakończonych działań, z drugiej strony — na podnoszeniu skuteczności omówionych metod w drodze zdobywanego doświadczenia.

Wydaje się, iż najlepszym ,poligonem doświadczalnym” jest organizowanie interdyscyplinarnych warsztatów dedykowanych konkretnym metodom, urządzeniom, które testowane będą w oparciu o odpowiednio zaaranżowane scenariusze. W tym wypadku maksyma practice makes perfect w pełni oddaje istotę problemu polegającego na ciągłym doskonaleniu swoich kwalifikacji i zdobywaniu praktycznego doświadczenia.

Działania w tym zakresie podejmowane są m.in. pod auspicjami European Network of Forensic Sciences Institute (ENFSI) w ramach praktycznych warsztatów terenowych Forensic Search and Recovery Clandestine Graves ${ }^{39}$. Spotykają się na nich eksperci rożnych specjalizacji, m.in. z zakresu geofizyki sądowej, archeolodzy sądowi, technicy

38 Za udzielone w tym zakresie konsultacje autor składa niniejszym podziękowania kierownikowi Katedry Medycyny Sądowej Uniwersytetu Medycznego we Wrocławiu prof. T. Jurkowi.

39 Por. http://enfsi.eu/agenda/forensic-search-and-recovery-clandestine-graves/ (dostęp: 10.02.2020). 
kryminalistyki, antropolodzy sądowi oraz lekarze medycyny sądowej ${ }^{40}$. Jest to doskonała okazja do wymiany doświadczeń oraz podnoszenia efektywności metod wykorzystywanych w procesie poszukiwań ukrytych zwłok. Wydaje się, iż w działaniach tego typu powinni również uczestniczyć przedstawiciele organów ścigania.

\section{Bibliografia}

Aries Ph., Człowiek i śmierć, Warszawa 1989.

Barone P.M., Geophysics and Archaeology at Crime Scenes, [w:] Multidisciplinary Approaches to Forensic Archaeology, red. P.M. Barone, W.J. Groen, Springer 2018.

Black S., Co mówiq zwłoki, Łódź 2019.

Borkowski T., Trzciński M., Sprawozdanie z badań archeologicznych na posesji przy ul. Polskiej Organizacji Wojskowej 27 w Sieradzu, pow. Sieradzki, woj. Łódzkie, działka 172/17. Egzemplarz sprawozdania znajduje się w Biurze Poszukiwań i Identyfikacji IPN we Wrocławiu.

Domańska E., Nekros. Wprowadzenie do ontologii martwego ciała, Warszawa 2017.

Gawliński A., Jak pozbyć się zwłok. Specyfika działania sprawców zabójstw i ich postępowanie ze zwłokami, Olsztynek 2018.

Jaworski R., Poligraficzny ,, test wydobywczy” przy poszukiwaniu ciala ofiary zabójstwa, „Wrocławskie Studia Sądowe” 4, 2012, nr 3, s. 50-59.

Konopka T., Strona M., Bolechała F., Zabójstwo z rozkawałkowaniem zwłok - mity i rzeczywistość, [w:] E. Gruza, M. Goc, T. Tomaszewski, Co nowego w kryminalistyce przeglad zagadnień z zakresu zwalczania przestępczości, Warszawa 2010.

Mazurkiewicz E., Kubacki A., Karczewski J., Poszukiwania miejsc pochówków w gruncie za pomoca nowoczesnych metod badawczych, [w:] V. Kwiatkowska-Wójcikiewicz, D. Wilk, J. Wójcikiewicz, Kryminalistyka a nowoczesne technologie, Kraków 2019.

Mazurkiewicz E., Łyskowski M., Zastosowanie metody georadarowej do badania miejsc pochówków na terenach zurbanizowanych, [w:] Kryminalistyka — jedność nauki i praktyki. Przeglad zagadnień z zakresu zwalczania przestępczości, red. M. Goc, T. Tomaszewski, R. Lewandowski, Warszawa 2016.

Ośka R., Lisowicz M., Wyszukiwanie zapachu zwłok ludzkich, Legionowo 2016.

Stojer-Polańska J., Lisowicz M., Gołębiowski J., Kryminalistyczne aspekty poszukiwania zwłok, ,Problemy Kryminalistyki” 289, 2015, nr 3.

Szleszkowski L. et al., Ecological aspects of unusual findings of animals nesting inside a mummified human corpse in natural conditions, „Forensic Science International” 289, 2018.

40 W dniach 27-29 kwietnia 2020 roku warsztaty takie odbędą się we Wrocławiu. Poprzednie edycje miały miejsce w Danii (2017) oraz Portugalii (2019).

Nowa Kodyfikacja Prawa Karnego 56, 2020

(C) for this edition by CNS 
Trzciński M., Współczesne metody poszukiwań ukrytych zwłok, „Acta Universitatis Lodziensis. Folia Iuridica" 83, 2018.

Zubańska M., Knut P., Niewykryte przestęstwa sprzed lat, nowoczesne narzędzia techniki kryminalistycznej i policyjne Zespoły do spraw Przestepstw Niewykrytych, czyli crimen grave non potest esse impunibile, „Problemy Kryminalistyki” 299, 2018, nr 1.

\section{Akty prawne}

Konstytucja Rzeczypospolitej Polskiej z dnia 2 kwietnia 1997 roku, Dz.U. 1997 Nr 78, poz. 483.

Ustawa z dnia 6 kwietnia 1990 roku o Policji, Dz.U. 1990 Nr 30, poz. 179 z późn. zm. Zarządzenie nr 48 Komendanta Głównego Policji z dnia 28 czerwca 2018 roku w sprawie prowadzenia przez Policję poszukiwania osoby zaginionej oraz postępowania w przypadku ujawnienia osoby o nieustalonej tożsamości lub znalezienia nieznanych zwłok oraz szczątków ludzkich, Dziennik Urzędowy Komendy Głównej Policji 2018, poz. 77.

\section{Źródła internetowe}

Portal „The Scotsman”: https://www.scotsman.com/news/crime/renee-and-andrew-macrae-man-arrested-43-years-after-disappearance-of-mother-and-son-1-5002093 (dostęp: 10.02.2020).

Strona internetowa European Network of Forensic Science Institutes: http://enfsi.eu/ agenda/forensic-search-and-recovery-clandestine-graves/ (dostęp: 9.02.2020).

Strona internetowa IPN: https://poszukiwania.ipn.gov.pl/ (dostęp: 4.02.2020).

Strona internetowa gazeta.pl: https://wiadomosci.gazeta.pl/wiadomosci/7,114883,24142937,morderstwo-a-potem-pocwiartowanie-zwlok-klotnia-bylych-kochankow.html\#s=BoxOpMT (dostęp: 6.02.2020).

Strona internetowa wikipedia.org: https://pl.wikipedia.org/wiki/Morderstwo_Katarzyny_Zowady (dostęp: 10.02.2020).

Strona internetowa wikipedia.org: https://pl.wikipedia.org/wiki/Georadar (dostęp: 10.02.2020).

Strona internetowa wyborcza.pl: http://warszawa.wyborcza.pl/warszawa/7,54420,2499 0271,poszukiwania-5-letniego-dawida-zukowskiego-wznowione-nowe-nagrania. html (dostęp: 6.02.2020).

\section{Critical of some methods of searching for hidden corpses}

\section{Summary}

In Poland, apart from law enforcement agencies, the Institute of National Remembrance also deals with the search for homicide victims due to the fact that war crimes and genocide are not subject to the statute of limitations. New technologies used in both 
criminalistics and forensic archaeology allow even after many years to find homicide victims. These methods have various effectiveness. The author presents some practical, critical remarks regarding the application of some of them.

Keywords: clandestine graves, forensic search, cadaver dogs, forensic geophysics 